\title{
ANALISIS LOKASI PEMBUANGAN LIMBAH PADAT DI KOTA TEGAL MENGGUNAKAN SISTEM INFORMASI GEOGRAFIS
}

\author{
Sigit Bayhu Iryantoni, Budi Santoso, Ananta Aji
}

Masuk: 27022018 / Diterima: 28062018 / Dipublikasi: 30062018 (c) 2018 Fakultas Hukum dan IImu Sosial UNDIKSHA dan IGI

\begin{abstract}
The increasing population population is a problem for the environment. Increased population will increase the amount of consumption and waste generated. Waste Solid (SW) becomes a problem that is not needed properly. SW deliber changes environmental balance that can cause contamination of soil, air and air. The problem of SW in Tegal City becomes a serious problem. TPA located in Muarareja Urban Village, the lease of the land has expired since November 2015. The need to study the determination of the landfill location is an immediate need. By utilizing Geographic Information System (GIS), is an ideal model in determining location based on data overlay method. GIS utilization with physical data analysis and conformity with Spatial Plan (RTRW). Obtained several location options that can be used as an alternative landfill location. Some government locations, 1) Pulosari District, Kab. Pemalang, 2) District Tonjong, Kab. Brebes, 3) Kedungbanteng Sub-district, Tegal Regency.
\end{abstract}

Key words: GIS; Waste Solid; Final Waste Place

\begin{abstract}
Abstrak Populasi penduduk yang semakin meningkat merupakan suatu permasalahan tersendiri bagi kondisi lingkungan. Peningkatan penduduk akan meningkatkan jumlah konsumsi dan sampah yang dihasilkan. Limbah padat atau waste solid (SW) menjadi masalah yang mendesak apabila penanganan dan pengelolaannya tidak dilakukan dengan baik. SW mengakibatkan perubahan keseimbangan lingkungan yang merugikan sehingga dapat mencemari tanah, air maupun udara. Masalah SW di Kota Tegal menjadi permasalahan serius. TPA yang berlokasi di Kelurahan Muarareja, sewa lahannya sudah berakhir sejak November 2015. Perlunya kajian penentuan lokasi TPA merupakan kebutuhan yang harus segera di lakukan. Dengan memanfaatkan Sitem Informasi Geografi (SIG), merupakan model yang ideal dalam menentukan lokasi berdasarkan metode overlay data. Pemanfaatn SIG dengan analisis data fisik dan kesesuaian dengan Rencana Tata Ruang Wilayah (RTRW). Diperoleh beberapa opsi lokasi yang dapat digunakan sebagai alternativ lokasi TPA. Beberapa lokasi diantaranya, 1) Kecamatan Pulosari, Kab. Pemalang, 2) Kecamatan Tonjong, Kab. Brebes, 3) Kecamatan Kedungbanteng, Kabupaten Tegal.
\end{abstract}

Kata kunci : SIG; Limbah Padat; TPA

\section{Pendahuluan}

Populasi penduduk, pertumbuhan ekonomi yang pesat akibat industrialisasi, dan meningkatnya standar kehidupan masyarakat di negara-negara berkembang termasuk di Indonesia akan berdampak

Sigit Bayhu Iryantoni, Budi Santoso, Ananta Aji Universitas Diponegoro

Semarang

sigitbayhuiryanthony@gmail.com pada meningkatnya produksi limbah (Minghua et al., 2009). Undang-Undang RI Nomor 32 Tahun 2009 mendefinisikan bahwa limbah adalah sisa suatu usaha dan atau kegiatan yang mempengaruhi lingkungan hidup. Suatu tatanan lingkungan hidup dapat tercemar atau menjadi rusak disebabkan oleh banyak hal, terutama oleh limbah. Limbah padat (sampah) adalah limbah atau buangan 
yang bersifat padat, terdiri dari zat atau bahan organik dan anorganik yang dianggap sudah tidak berguna lagi. Limbah padat bisa berasal dari buangan rumah tangga, pasar, pabrik, dan lain sebagainya yang harus dikelola dengan baik agar tidak membahayakan kehidupan manusia dan lingkungannya (Tarmidi, 2004).

Limbah padat atau waste solid (SW) menjadi masalah yang mendesak apabila penanganan dan pengelolaannya tidak dilakukan dengan baik. SW mengakibatkan perubahan keseimbangan lingkungan yang merugikan sehingga dapat mencemari tanah, air maupun udara. Penanganan SW diperkotaan relatif lebih sulit dibandingkan di desa. Masalah yang sering muncul dalam penanganan SW perkotaan adalah masalah biaya operasional yang tinggi dan semakin sulitnya ruang yang tepat untuk pembuangan. Pemerintah kota sering menghadapi masalah di luar kemampuan otoritasnya (Sujauddin, Huda, \& Hoque, 2008), terutama karena lemahnya organisasi, sumber daya keuangan, kompleksitas dan sistem multidimensi (Burnley, 2007). Kebanyakan kota-kota di Indonesia hanya mampu mengumpulkan dan membuang $60 \%$ dari seluruh produksi sampahnya (Wibowo, 2008).

Negara-negara berkembang dikawasan Asia banyak mengalami peningkatan limbah padat (SW). Sebagian besar komposisi SW adalah limbah organik biodegradable (dapat hancur atau terurai oleh organisme hidup). India menghasilkan 0,2-0,5 kg/orang/hari SW dengan jumlah penduduk 217 juta jiwa (Dhokhikah \& Trihadiningrum, 2012). Jakarta dan Surabaya menghasilkan sekitar $65 \%$ dan $72,41 \%$ limbah organik biodegradable (Pasang, Moore, \& Sitorus, 2007), (Trihadiningrum, 2006).

Tempat pembuangan akhir (TPA) merupakan masalah yang kompleks pada setiap kota besar, dengan jumlah penduduk yang tinggi. TPA akan mengalami perubahan kondisi mengikuti perkembangan indikator seperti: suhu tinggi, perubahan komposisi gas, tekanan gas yang meningkat, peningkatan migrasi lindi, dan pergerakan lereng (Jafari, Stark, \& Thalhamer, 2017).

Masalah SW di Kota Tegal menjadi permasalahan serius. TPA yang berlokasi di Kelurahan Muarareja, sewa lahannya sudah berakhir sejak November 2015. Saat ini Kota Tegal tidak memiliki TPA yang terstandarisasi nasional. Sejumlah tempat pengolahan sampah terpadu (TPST) yang dibangun disejumlah kelurahan belum berfungsi optimal. Pemkot Tegal berencana membangun TPA Bokong Semar di Kelurahan Kaligangsa untuk mengatasi masalah persampahan. Penentuan lokasi TPA tersebut bertentangan dengan Peraturan Daerah (PERDA) Nomor 4 Tahun 2012 tentang RTRW Kota Tegal Tahun 20112031. Kawasan yang direncanakan dibangun TPA merupakan kawasan bekas tambak yang peruntukannya adalah untuk kawasan budidaya perikanan. Secara hidrogeologi, TPA tidak mungkin dibangun di atas tanah bekas tambak karena permukaan air sudah tinggi (Hudiyanto, 2017).

Kebutuhan lahan untuk lokasi TPA di Kota Tegal menjadi kendala karena keterbatasan ruang. Perencanaan TPA regional menjadi suatu pilihan diberbagai daerah. Beberapa TPA regional telah dibangun di Indonesia, namun dalam pelaksanaannya TPA regional tersebut lebih banyak menimbulkan konflik karena lebih banyak kerugian yang diderita oleh daerah yang menjadi lokasi TPA dibandingkan keuntungan yang didapat. Hal ini diperparah dengan adanya istilah "not in my back yard" (NIMBY) yang memberi kesan bahwa TPA regional akan membawa dampak buruk bagi daerah yang menjadi lokasi TPA tersebut (Windyawati, 2000). 
Pemanfaatan teknologi sitem informasi geografis (SIG) dapat digunakan dalam permodelan berbagai bidang bahkan sampai dengan permodelan limbah. SIG menggabungkan data spasial (peta, foto udara, citra satelit) dengan database informasi kuantitatif, kualitatif dan deskriptif lainnya (Nishant.T, Prakash M.N, 2010). Proses menentukan lokasi pembuangan limbah padat perkotaan memang sulit dan memakan waktu yang lama. Prosedur yang sistematis harus ditaati dan dilakukan dengan hati-hati (Babalola \& Busu, 2011). Permasalah inilah yang mencoba dipecahkan oleh peneliti dengan metode pemodelan SIG untuk memperoleh lokasi pembuangan limbah padat perkotaan yang ideal.

\section{Metode}

Metode untuk mengevaluasi lokasi TPA yang baru mempertimbangkan beberapa parameter seperti jarak ke jalan, permukiman, elemen infrastruktur utama dan kecenderungan tanah untuk mencairkan kontaminan (Sumathi, Natesan, \& Sarkar, 2008). Beberapa kriteria dibahas, seperti produksi limbah, jarak dari rumah, tinggi muka air tanah, tata guna lahan, kemiringan lahan, jaringan transportasi, dan lain-lain (EI Maguiri, Kissi, Idrissi, \& Souabi, 2016). Kriteria subkelas utama yang digunakan untuk analisis spasial dalam penelitian ini adalah geologi, geomorfologi, kemiringan, drainase, populasi, jarak dari jalan utama, jarak dari aliran sungai dan jarak dari drainase. Data-data tersebut merupakan kriteria dan sub kriteria yang digunakan dalam pengembangan database SIG (Nishant.T, Prakash M.N, 2010). Sebagian besar peneliti menggunakan pemodelan SIG untuk mempermudah permodelan keruangan penentuan lokasi TPA (Abujayyab, Ahamad, Yahya, Bashir, \& Aziz, 2016), (Siddiqui, Everett, \& Vieux, 1996), (Jafari et al., 2017), (Cheng \& Thompson, 2016).

Tabel 1. Kriteria dan Sub kriteria dalam Permodelan SIG

\begin{tabular}{ll}
\hline \multirow{3}{*}{ Kriteria fisik } & Geologi \\
\cline { 2 - 2 } & Geomorfologi \\
\hline \multirow{3}{*}{ Kriteria sosial ekongan } \\
\hline Drainase \\
\hline & Populasi \\
\hline Jarak dari jalan utama \\
\hline Jarak dari aliran sungai \\
\hline Jarak dari drainse \\
\hline
\end{tabular}

Sumber: (Nishant.T, Prakash M.N, 2010)

Data dikumpulkan, kemudian dirubah menjadi format shapefile (Shp) sehingga dapat digunakan dalam software ArcGIS 10.2.1. Setalah dilakukan konversi dari berbagai data ke format yang sesuai dengan software SIG, dilakukan pemberian data atribut yang sesuai dengan apa yang sudah ada. Dimulai dengan pemberian topologi nama yang sudah ada menjadi data inti dalam software. Dari berbagai macam jenis data: geomorfologi, geologi, drainase, lereng, sungai, populasi penduduk, dan jalan, diberikan bobot dalam setiap parameter yang akan digunakan dalam membuat permodelan data. 
Tabel 2. Bobot yang Digunakan dalam Setiap Kriteria

\begin{tabular}{lc}
\hline \multicolumn{1}{c}{ Peta Parameter } & Bobot \\
\hline Geologi & 8 \\
\hline Geomorfologi & 8 \\
\hline Kelerengan & 7 \\
\hline Drainase & 6 \\
\hline Populasi & 5 \\
\hline Jarak dari jalan utama & 4 \\
\hline Jarak dari aliran sungai & 6 \\
\hline Jarak dari drainse & 6 \\
\hline
\end{tabular}

Sumber: (Nishant.T, Prakash M.N, 2010)

\section{Hasil dan Pembahasan}

\subsection{Karakteristik Area Studi}

Kota Tegal merupakan salah satu wilayah di Provinsi Jawa Tengah yang berada di sebelah barat dan terletak di pantai utara Pulau Jawa. Secara astronomis terletak pada $109^{\circ} 08^{\prime}$ sampai $109^{\circ} 10^{\prime}$ garis Bujur Timur dan $6^{\circ} 50^{\prime}$ sampai $6^{0} 53^{\prime}$ garis Lintang Selatan. Wilayah Kota tegal berbatasan langsung dengan tiga kabupaten yaitu: Kabupaten Pemalang (sebelah timur), Kabupaten Tegal (sebelah selatan), dan Kabupaten Brebes (sebelah barat).

Pada tahun 1987, Kota Tegal mengalami pemekaran wilayah yang berasal dari Kabupaten Tegal, ditambah dengan wilayah Kabupaten Brebes, yang dikenal dengan sebutan "Bokong Semar". Luas wilayah saat ini adalah $39,68 \mathrm{~km}^{2}$ atau sekitar $0,11 \%$ dari luas Jawa Tengah.
Kota Tegal terbagi menjadi empat kecamatan: Tegal Selatan, Tegal Barat, Tegal Timur, dan Margadana. Wilayah kecamatan terluas yaitu Tegal Barat $\left(12,13 \mathrm{~km}^{2}\right)$ atau sekitar $38,13 \%$ luas wilayah Kota Tegal.

Penduduk Kota Tegal tahun 2016 sebanyak 247.21 jiwa. Dibandingkan dengan jumlah penduduk tahun 2015, penduduk Kota Tegal mengalami pertumbuhan sebesar 0,44\%. Kepadatan penduduk tahun 2016 mencapai 6.230 jiwa $/ \mathrm{km}^{2}$ (BPS, 2017). Pertumbuhan penduduk yang pesat diikuti pula oleh pertumbuhan industrinya. Industri yang berkembang di Kota Tegal seperti terlihat pada Tabel 3. Lokasi area studi ditunjukkan pada gambar 1 .

Tabel 3. Jenis limbah padat dan komposisinya di Kota Tegal

\begin{tabular}{clc}
\hline No & \multicolumn{1}{c}{$\begin{array}{c}\text { Jenis Limbah } \\
\text { Padat }\end{array}$} & $\begin{array}{c}\text { Komposisi } \\
(\%)\end{array}$ \\
\hline 1 & Organik & 40,25 \\
\hline 2 & Kertas & 6,25 \\
\hline 3 & Kaca & 3 \\
\hline 4 & Plastik & 40,4 \\
\hline 5 & Logam & 0,15 \\
\hline 6 & Kayu & 3,6 \\
\hline 7 & Kain & 1,05 \\
\hline 8 & Karet & 2,3 \\
\hline 9 & Lain-lain & 3 \\
\hline \multicolumn{2}{c}{ Sumber: (http://ciptakarya.pu.go.id) }
\end{tabular}




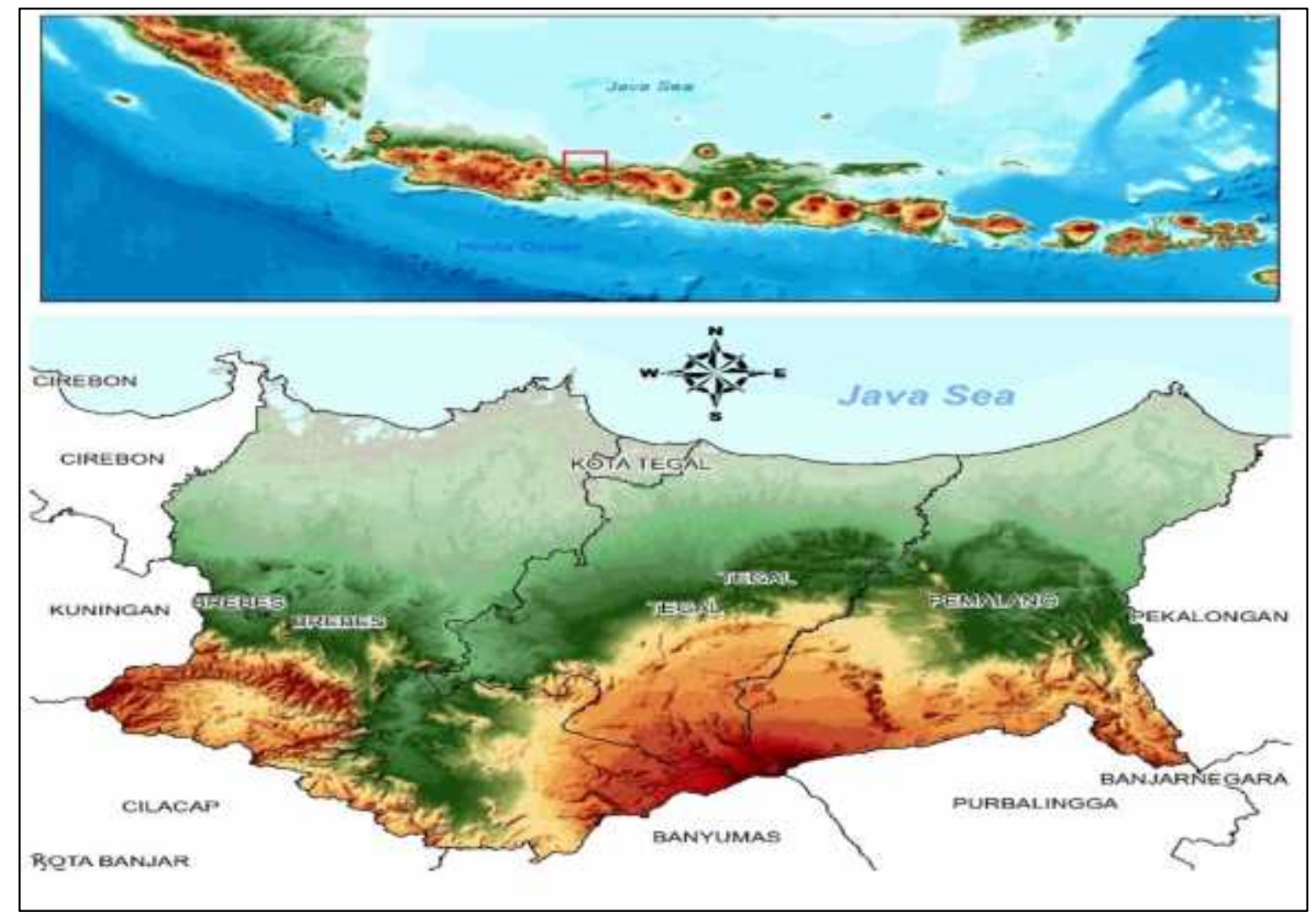

Gambar 1. Cakupan lokasi penelitian

\subsection{Analisis Kesesuaian Lahan untuk Pembuangan Limbah Padat Perkotaan}

Tempat pembuangan akhir dengan model sanitary landfill merupakan salah satu solusi tepat untuk mengatasi masalah persampahan atau limbah padat (SW). Akan tetapi, belum semua pemerintah daerah mampu menyediakan TPA dengan sistem ini. Salah satu faktor yang mempengaruhi adalah kebutuhan lahan untuk lokasi TPA yang cukup luas. Untuk mengatasi permasalahan ini, langkah yang dilakukan adalah dengan mengupayakan pengelolaan SW secara terpadu dan terintegrasi antar pemerintah daerah. TPA regional merupakan strategi yang ditempuh untuk mewujudkan hal tersebut.

Perda Provinsi Jawa Tengah No.6 tahun 2010 tentang RTRW wilayah Provinsi telah menyebutkan bahwa TPA regional di Jawa Tengah direncanakan berada di wilayah Metropolitan Kedungsepur, Metropolitan Bregasmalang, Metropolitan Subosukawonosraten, Purwomanggung dan Petanglong.

TPA regional Bregasmalang direncanakan untuk melayani Kabupaten Brebes, Kota Tegal, Kabupaten Tegal, dan Kabupaten Pemalang. Pembuatan TPA baru, terutama TPA dengan sistem sanitary landfill memang sangat dibutuhkan oleh ke empat pemerintah daerah ini. Menindaklanjuti dari RTRW Provinsi Jawa Tengah, maka pemerintah daerah Kabupaten Tegal dalam rencana tata ruangnya telah menentukan lokasi TPA regional Bregasmalang berada di Desa Kertasari, Kecamatan Surodadi, Kabupaten Tegal (BAPPEDA, 2012).

Penetapan lokasi TPA regional di Kecamatan Surodadi tidak diiringi dengan 
kesesuaian tata guna lahan karena di daerah tersebut sebagian besar wilayahnya berupa sawah produktif dan terdapat jalur SUTET dengan tegangan 500 kilovolt (KV). Keberadaan sawah menunjukkan bahwa muka air tanah di daerah tersebut dangkal sehingga tidak dapat digali terlalu dalam untuk dijadikan TPA. Studi peninjauan kembali kelayakan lokasi TPA regional Bregasmalang dilakukan oleh Apritama (Apritama, 2016), hasilnya adalah kebutuhan lahan untuk zona penimbunan TPA adalah 70,2 $\mathrm{Ha}$ dengan rencana pelayanan 20 tahun (2015-2035). Lokasi terpilih yang lebih sesuai berada di Desa Kedungbanteng, Kecamatan Kedung Banteng, Kabupaten Tegal.

Kota Tegal sendiri belum menetapkan lokasi yang sesuai untuk pembangunan TPA dalam rencana tata ruangnya. Kabar yang muncul dibawah kepemimpinan walikota sekarang, Kota Tegal berencana membangun TPA baru sendiri dikotanya. Nama TPA tersebut adalah "Bokong Semar".
Hasil analisis tingkat kesesuaian lahan untuk pembuangan limbah padat perkotaan di empat wilayah pemerintahan (Kota Tegal, Kabupaten Tegal, Kabupaten Pemalang, dan Kabupaten Brebes) dapat dilihat di Tabel 4.

Berdasarkan analisis data tersebut, sangat jelas bahwa Kota Tegal tidak memiliki lahan yang cocok (kriteria highvery high) untuk mendirikan TPA baru, terutama TPA dengan model sanitary landfill yang membutuhkan lahan cukup luas dengan sistem pengolahan yang sangat ketat. Solusi mendesak tentang permasalahan SW di Kota Tegal yang semakin hari semakin menumpuk dan tidak memiliki tempat pembuangan akhir yang layak adalah dengan ikut berpartisipasi dalam pembangunan TPA regional Bregasmalang.

Peta kesesuaian lahan untuk pembuangan limbah padat perkotaan untuk wilayah Kota Tegal, Kabupaten Tegal, Kabupaten Pemalang, dan Kabupaten Brebes dapat dilihat pada gambar 2.

Tabel 4. Tabel Analisis Tingkat Kesesuaian Lahan untuk Pembuangan Limbah Padat Perkotaan

\begin{tabular}{lcccccc}
\hline $\begin{array}{l}\text { Kabupaten / } \\
\text { Kecamatan }\end{array}$ & \multicolumn{5}{c}{ Kesesuaian Area (Hektar) } \\
\hline \multicolumn{1}{c}{ Kecamatan } & Medium & Low & Very low & $\begin{array}{c}\text { Very } \\
\text { high }\end{array}$ & High & Total \\
\hline Kab. Brebes & 48341.65 & 56743.29 & 24831.40 & 7292.97 & 39804.80 & 177014.31 \\
\hline Banjarharjo & 6821.54 & 5594.73 & 194.29 & 131.23 & 3075.41 & 15817.20 \\
Bantarkawung & 9008.11 & 6854.35 & 190.79 & 650.28 & 4254.98 & 20958.52 \\
Brebes & 200.94 & 6023.08 & 3289.20 & & & 9513.21 \\
Bulakamba & 227.44 & 5310.72 & 6180.57 & & & 11718.73 \\
Bumiayu & 4545.81 & 1588.76 & 173.63 & & 1736.53 & 8044.74 \\
Jatibarang & 408.85 & 3070.59 & 540.16 & & 21.13 & 4040.74 \\
Kersana & 1359.17 & 1315.18 & & & & 2674.35 \\
Ketanggungan & 4502.41 & 4775.07 & 1264.90 & 71.08 & 4734.58 & 15348.04 \\
Larangan & 4423.56 & 5349.26 & 3412.30 & 7.66 & 2841.80 & 16034.59 \\
Losari & 377.71 & 5142.62 & 3702.39 & & & 9222.72 \\
Paguyangan & 4998.33 & 493.49 & & 369.74 & 4774.04 & 10635.60 \\
Salem & 4313.31 & 372.78 & & 3277.69 & 8779.28 & 16743.06
\end{tabular}




\begin{tabular}{|c|c|c|c|c|c|c|}
\hline Sirampog & 1746.26 & 72.85 & & 1608.68 & 3914.51 & 7342.49 \\
\hline Songgom & 2626.42 & 2199.01 & & & 421.20 & 5246.63 \\
\hline Tanjung & 385.11 & 4201.01 & 2532.72 & & 0.18 & 7119.02 \\
\hline Tonjong & 2085.23 & 182.32 & & 1176.60 & 5250.47 & 8694.61 \\
\hline Waduk Cacaban & 186.13 & 210.68 & & & 0.68 & 397.49 \\
\hline Wanasari & 125.33 & 3986.79 & 3350.44 & & & 7462.55 \\
\hline Kota Tegal & 520.94 & 3174.94 & & & 0.29 & 3696.16 \\
\hline Margadana & 108.74 & 1190.23 & & & & 1298.97 \\
\hline Tegal Barat & 121.76 & 928.99 & & & & 1050.75 \\
\hline Tegal Selatan & 247.24 & 424.74 & & & 0.29 & 672.27 \\
\hline Tegal Timur & 43.19 & 630.98 & & & & 674.17 \\
\hline Kab. Tegal & 33565.48 & 25707.46 & 2931.85 & 3127.07 & 32742.27 & 98074.13 \\
\hline Adiwerna & 427.96 & 1637.93 & 225.00 & & 77.13 & 2368.03 \\
\hline Balapulang & 4854.55 & 577.66 & 10.12 & 210.00 & 2969.46 & 8621.79 \\
\hline Bojong & 703.40 & 6.84 & & 702.06 & 5362.55 & 6774.84 \\
\hline Bumijawa & 2991.14 & 288.85 & 0.36 & 514.25 & 7123.82 & 10918.41 \\
\hline Dukuhturi & 193.46 & 1308.37 & 210.86 & & & 1712.69 \\
\hline Dukuhwaru & 1107.24 & 20.64 & & & 1504.44 & 2632.32 \\
\hline Jatinegara & 4068.22 & 429.64 & & 564.70 & 5883.64 & 10946.21 \\
\hline Kedung Banteng & 2688.40 & 1045.78 & & 585.42 & 3955.27 & 8274.88 \\
\hline Kramat & 253.46 & 2993.66 & 1139.54 & & & 4386.65 \\
\hline Lebaksiu & 3385.21 & 683.67 & & & 627.32 & 4696.20 \\
\hline Margasari & 5460.85 & 1394.06 & 2.65 & 526.01 & 2699.85 & 10083.42 \\
\hline Pagerbarang & 2391.67 & 0.01 & & 24.63 & 2164.03 & 4580.34 \\
\hline Pangkah & 1662.41 & 1974.21 & 109.22 & & 18.75 & 3764.59 \\
\hline Slawi & 1058.15 & 150.44 & & & 171.68 & 1380.27 \\
\hline Suradadi & 285.02 & 4548.99 & 1049.01 & & & 5883.01 \\
\hline Talang & 162.03 & 1540.56 & 185.09 & & & 1887.69 \\
\hline Tarub & 696.48 & 2102.15 & & & 5.01 & 2803.64 \\
\hline Warureja & 1175.81 & 5004.02 & & & 179.34 & 6359.16 \\
\hline Kab. Pemalang & 36680.2 & 44414.4 & 8142.3 & 4128.6 & 20129.4 & 113495.0 \\
\hline Ampelgading & 2164.7 & 1860.3 & & 320.5 & 1213.3 & 5558.8 \\
\hline Bantarbolang & 5514.9 & 4301.9 & & 860.7 & 3975.7 & 14654.3 \\
\hline Belik & 3985.9 & 7435.5 & & & 1217.8 & 12639.2 \\
\hline Bodeh & 2719.2 & 2391.8 & & 902.5 & 2717.6 & 8731.1 \\
\hline Comal & 976.2 & 1642.9 & & 83.4 & 23.0 & 2725.5 \\
\hline Moga & 2937.4 & 454.1 & & 110.0 & 776.6 & 4278.1 \\
\hline Pemalang & 1545.6 & 3471.8 & 4024.9 & & 906.6 & 9948.9 \\
\hline Petarukan & 1345.9 & 5092.0 & 1297.2 & & 201.4 & 7936.5 \\
\hline Pulosari & 2843.7 & 2192.2 & & 259.8 & 3859.2 & 9154.9 \\
\hline Randudongkal & 3564.7 & 1350.2 & 446.4 & 888.5 & 2950.0 & 9199.8 \\
\hline Taman & 652.4 & 4482.9 & 1491.9 & & & 6627.3 \\
\hline Ulujami & 1254.4 & 4134.9 & 881.9 & 60.1 & 388.2 & 6719.6 \\
\hline Warungpring & 680.7 & & & 342.6 & 1423.7 & 2447 \\
\hline Watukumpul & 6494.3 & 5603.0 & & 300.5 & 476.2 & 12874 \\
\hline
\end{tabular}




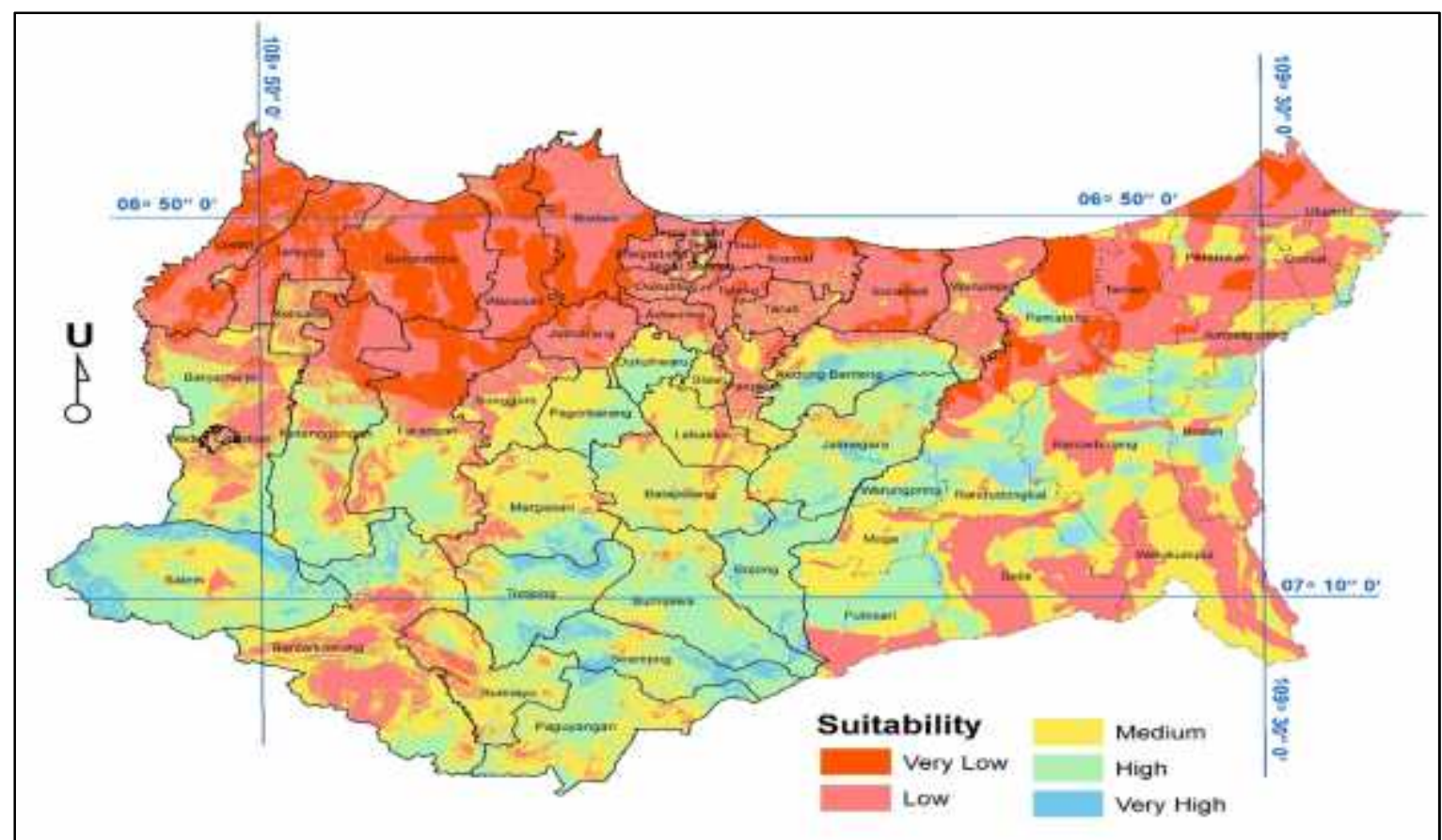

Gambar 2. Peta Kesesualan Lahan untuk Pembuangan Lımbah Padat Perkotaan

3.3 Overlay Peta Rencana Pola Ruang dengan Kesesuaian Lahan untuk Pembuangan Limbah Padat Perkotaan

Setelah mendapatkan peta kesesuaian lahan untuk lokasi pembuangan limbah padat perkotaan, maka langkah selanjutnya adalah melakukan tumpang susun (overlay) dengan peta pola ruang dari ke empat wilayah (Kota Tegal, Kabupaten Tegal, Kabupaten Pemalang dan Kabupaten Brebes). Gambar 3, menunjukkan peta rencana pola ruang ke empat wilayah.

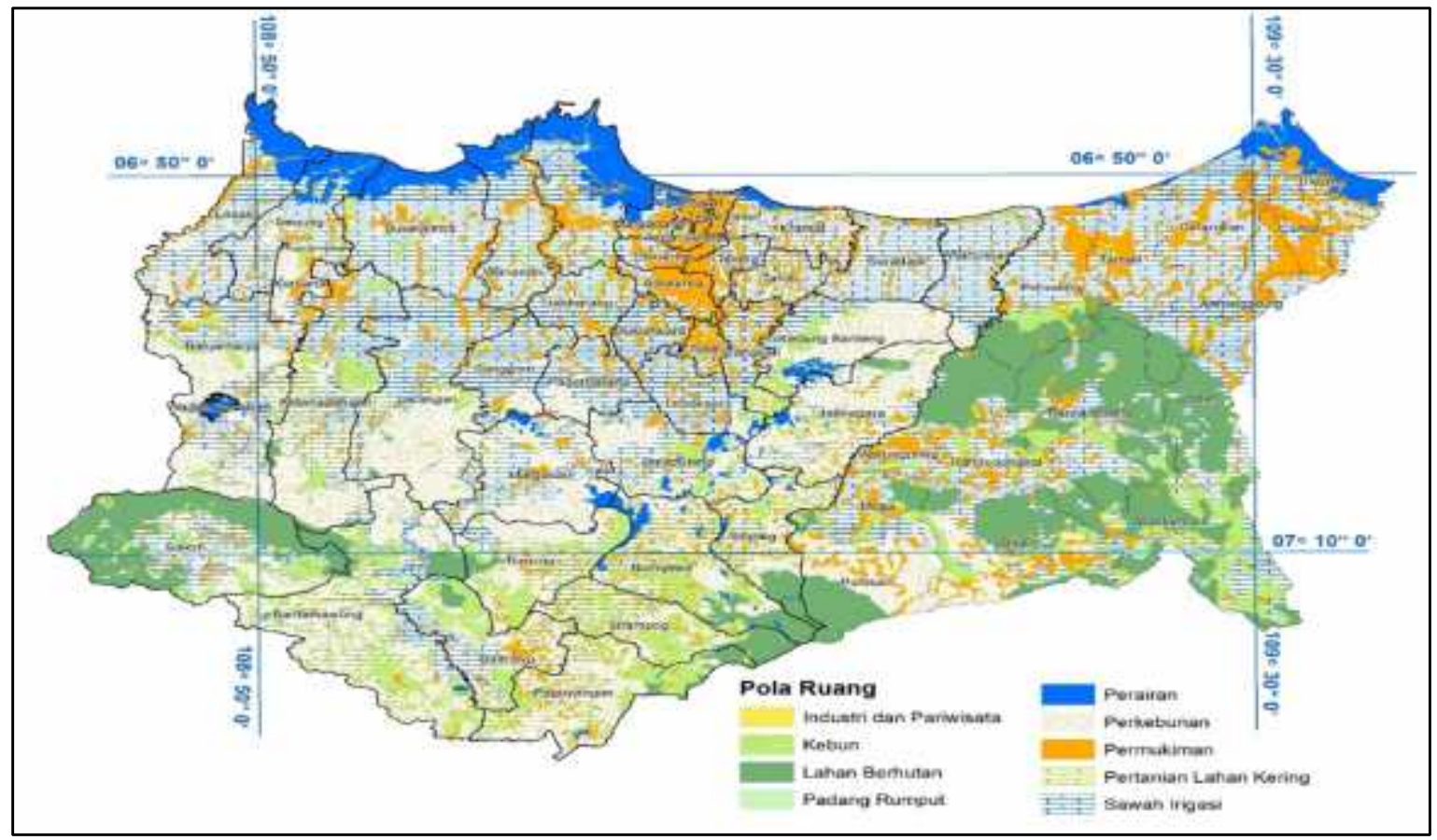

Gambar 3. Peta Rencana Pola Ruang Wilayah (RTRW), Wilayah penelitian 


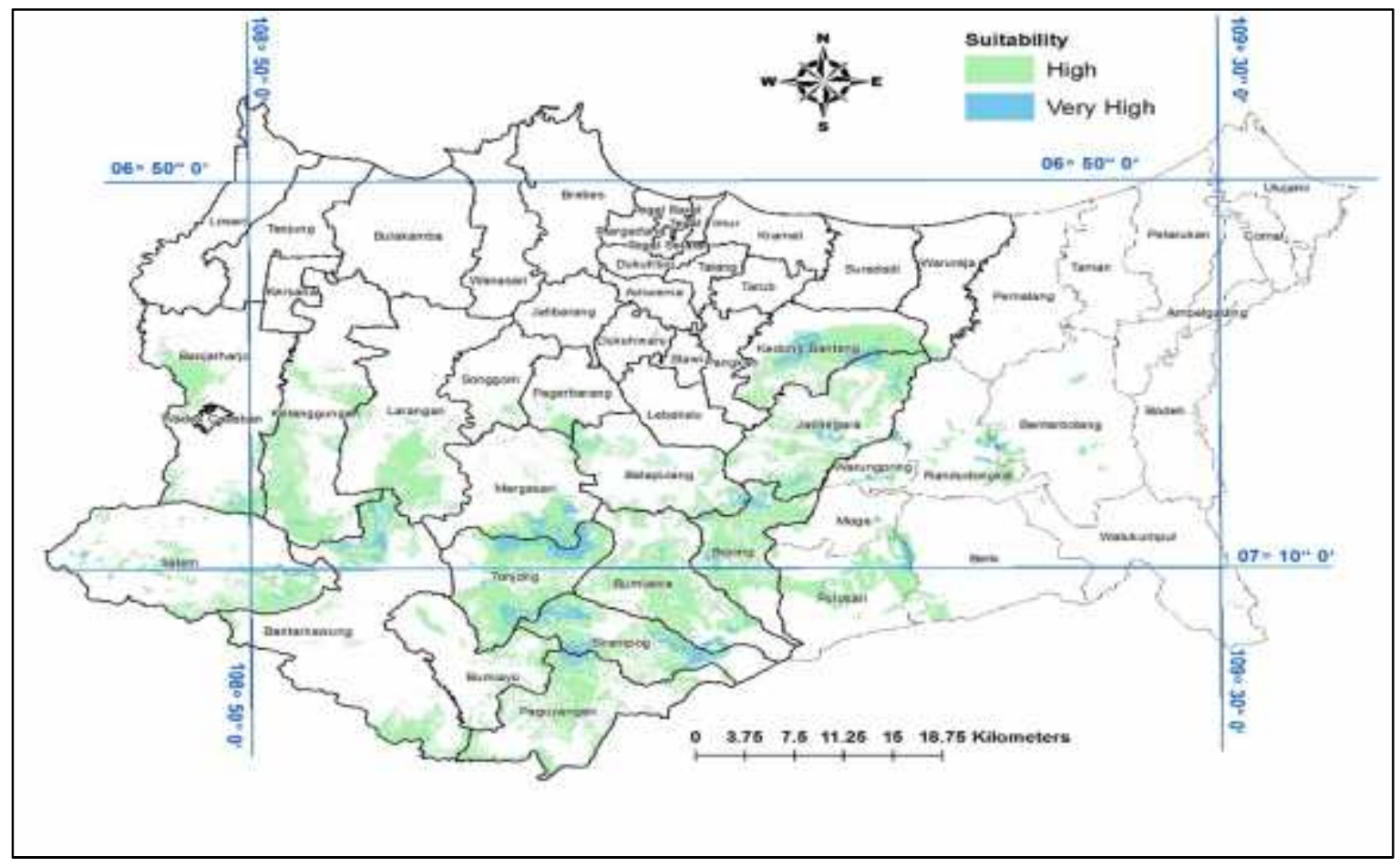

Gambar 4. Peta Kesesuaian Lokasi Pembuangan Limbah Padat Perkotaan

Hasil dari proses overlay ke empat wilayah adalah peta kesesuaian lokasi untuk pembuangan limbah padat perkotaan. Kota Tegal sama sekali tidak memiliki wilayah yang sesuai untuk pembuatan TPA. Lokasi yang memungkinkan untuk dibangun TPA Regional Bregasmalang adalah di wilayah Kabupaten Tegal, Kabupaten Brebes, dan Kabupaten pemalang.

\subsection{Analisis Penentuan Lokasi Pembuangan Limbah Padat Perkotaan}

TPA regional Bregasmalang memerlukan lahan yang cukup luas untuk menampung sampah dari ke empat kabupaten/kota (Kota Tegal, Kab. Tegal, Kab. Pemalang, Kab. Brebes). TPA ini direncanakan dapat melayani persampahan wilayah-wilayah tersebut selama 20 tahun. TPA regional Bregasmalang diasumsikan untuk memiliki fasilitas 3R (reuse, reduce, recycle) yang dapat mereduksi sampah hingga $30 \%$. Hasil dari proyeksi kebutuhan sampai tahun 2035 adalah 70,4 Ha (Apritama, 2016).

TPA regional Bregasmalang tidak bisa melayani semua wilayah di Kabupaten Tegal, Kabupaten Brebes, dan Kabupaten Pemalang. Beberapa faktor yang menyebabkan hal ini diantaranya adalah jarak dari daerah pelayanan ke TPA, kondisi TPA milik kabupaten yang masih beroperasi, dan efektivitas pembuangan apabila sampah harus di angkut semuanya ke TPA regional.

Berdasarkan analisis yang telah dilakukan untuk menentukan lokasi pembuangan limbah padat perkotaan, penelitian ini mencoba memberikan daftar pilihan lokasi yang ideal dengan berbagai kendalanya. Peneliti mengusulkan tiga lokasi yang paling potensial (kriteria very high) untuk dibangun TPA regional Bregasmalang, yaitu: Kecamatan Pulosari (Kab. Pemalang), Kecamatan Tonjong (Kab. Brebes) dan Kecamatan Kedungbanteng (Kab. Tegal). Lebih rinci dapat dilihat pada tabel 6 . 
Tabel 5. TPA yang Masih Aktif Di Kota/Kabupaten

\begin{tabular}{ll}
\hline \multicolumn{1}{c}{ Wilayah } & \multicolumn{1}{c}{ TPA yang Masih Aktif } \\
\hline Kota Tegal & - Tidak ada \\
\hline Kabupaten Tegal & TPA Panunjah \\
& (Desa Panunjah, Kec. Kedungbanteng) \\
\hline Kabupaten Brebes & TPA Regional Rawabaju (Kec. Songgom), \\
& - TPA Kaliwingi \\
& (Kec. Brebes), \\
- & TPA Kubangwaru \\
& (Kec. Ketanggungan), \\
& - TPA Kalijurang \\
& (Kec. Tonjong) \\
& - TPA Pesalakan \\
& (Desa Pegongsoran, Kec. Pemalang) \\
\hline Kabupaten Pemalang &
\end{tabular}

Tabel 6. Usulan lokasi Pembuangan Limbah Padat Perkotaan Beserta Kendalanya

\begin{tabular}{|c|c|c|c|c|}
\hline \multirow[t]{2}{*}{ No } & \multicolumn{2}{|c|}{ Lokasi } & \multicolumn{2}{|l|}{ Kendala } \\
\hline & Kabupaten & Kecamatan & $\begin{array}{c}\text { RTRW } \\
\text { (Kawasan Lindung) }\end{array}$ & $\begin{array}{l}\text { Jarak dari } \\
\text { Ibukota } \\
\text { Kabupaten }\end{array}$ \\
\hline 1 & Pemalang & $\begin{array}{l}\text { Pulosari } \\
(2413,5 \mathrm{Ha})\end{array}$ & $\begin{array}{l}\text { - Kawasan hutan lindung }(2036 \mathrm{Ha}), \\
\text { - Kawasan resapan air (180 Ha), } \\
\text { - Kawasan sekitar mata air, } \\
\text { - Kawasan cagar budaya dan ilmu } \\
\text { pengetahuan Batursari, } \\
\text { - Kawasan rawan bencana (tanah longsor), }\end{array}$ & \\
\hline 2 & Brebes & $\begin{array}{l}\text { Tonjong } \\
(1146,2 \mathrm{Ha})\end{array}$ & $\begin{array}{l}\text { - Kawasan resapan air (200 Ha), } \\
\text { - Kawasan sempadan mata air, } \\
\text { - Kawasan cagar budaya } \\
\text { (makam, candi, dan fosil Kalijurang), } \\
\text { - Kawasan rawan bencana } \\
\text { (tanah longsor), } \\
\text { - Kawasan imbuhan/cekungan air Tegal- } \\
\text { Brebes, } \\
\text { - Kawasan imbuhan/cekungan air Lebaksiu, }\end{array}$ & $70 \mathrm{~km}$ \\
\hline 3 & Tegal & $\begin{array}{l}\text { Kedungbanteng } \\
(578,6 \mathrm{Ha})\end{array}$ & $\begin{array}{l}\text { - Kawasan resapan air (62 Ha), } \\
\text { - Sumber mata air Curug Kaliwiru, } \\
\text { - Sumber mata air Kalisusu, } \\
\text { - Kawasan sekitar Waduk Cacaban, } \\
\text { - Kawasan cagar budaya: } \\
\text { (Situs Semedo), } \\
\text { - Kawasan rawan bencana alam } \\
\text { (longsor,kekeringan, kebakaran lahan) } \\
\text { - Kawasan lindung di luar kawasan hutan } \\
\text { yang memiliki kriteria fisiografi seperti } \\
\text { hutan lindung (249 Ha). }\end{array}$ & $7 \mathrm{~km}$ \\
\hline
\end{tabular}




\section{Penutup}

Penentuan lokasi pembuangan limbah padat perkotaan perlu suatu kajian yang mendalam dan melibatkan beberapa disiplin ilmu pengetahuan. Berdasarkan hasil analisis menggunakan pendekatan keruangan melalui Sistem Informasi Geografis (SIG), Kota Tegal tidak mempunyai wilayah yang suitable untuk pembuatan TPA, apalagi untuk TPA dengan model sanitary landfill. Kota Tegal sebaiknya ikut berpartisipasi dalam rencana pembangunan TPA Regional Bregasmalang sesuai dengan RTRW Provinsi Jawa Tengah. Ada 3 alternatif wilayah untuk penempatan TPA ini, yaitu: 1) Kecamatan Pulosari, Kab. Pemalang, 2) Kecamatan Tonjong, Kab. Brebes, 3) Kecamatan Kedungbanteng, Kabupaten Tegal.

TPA Regional Bregasmalang merupakan wujud pengelolaan sampah secara terpadu dan terintegrasi antar Pemerintah Daerah. Harapannya agar semua Pemeritah Daerah mentaati semua peraturan terkait pembangunan TPA Regional tersebut sehingga konflik, baik vertikal maupun horizontal dapat diminimalisir.

\section{Daftar Pustaka}

Abujayyab, S. K. M., Ahamad, M. S. S., Yahya, A. S., Bashir, M. J. K., \& Aziz, H. A. (2016). GIS modelling for new landfill sites: critical review of employed criteria and methods of selection criteria. IOP Conference Series: Earth and Environmental Science, 37(1), 12053.

Apritama, M. R. (2016). Studi Pemilihan Lokasi TPA Regional Bregasmalang (Brebes, Tegal, Slawi, Pemalang). Jurnal Teknik Lingkungan UNDIP, 5(2), 1-8.

Babalola, A., \& Busu, I. (2011). Selection of Landfill Sites for Waste solid Treatment in Damaturu Town-Using GIS Techniques. Journal of
Environmental Protection, 2(March), $1-10$.

BAPPEDA. (2012). Rencana Tata Ruang Wilayah Kabupaten Tegal Tahun 2012-2032. Kabupaten Tegal: Badan Perencanaan Pembangunan Daerah Kabupaten Tegal.

BPS. (2017). Kota Tegal Dalam Angka. Tegal: BPS Kota Tegal.

Burnley, S. J. (2007). A review of municipal waste solid composition in the United Kingdom. Waste Management, 27(10), 1274-1285.

Cheng, C., \& Thompson, R. G. (2016). Application of boolean logic and GIS for determining suitable locations for Temporary Disaster Waste Management Sites. International Journal of Disaster Risk Reduction, 20, 78-92.

Dhokhikah, Y., \& Trihadiningrum, Y. (2012). Waste solid Management in Asian Developing Countries: Challenges and Opportunities. J. Appl. Environ. Biol. Sci. Journal of Applied Environmental and Biological Sciences, 2(7), 329-335.

El Maguiri, A., Kissi, B., Idrissi, L., \& Souabi, S. (2016). Landfill site selection using GIS, remote sensing and multicriteria decision analysis: case of the city of Mohammedia, Morocco. Bulletin of Engineering Geology and the Environment, 75(3), 1301-1309.

Hudiyanto, W. (2017). Rencana Pembangunan TPA Bokong Semar Sebaiknya Ditinjau Ulang. Retrieved January 1, 2017, from

Jafari, N. H., Stark, T. D., \& Thalhamer, T. (2017). Spatial and temporal characteristics of elevated temperatures in municipal waste solid landfills. Waste Management, 59, 286-301.

Kementerian PUPR. (2016). Baseline Informasi Persampahan. Retrieved January 1, 2017, from 
Minghua, Z., Xiumin, F., Rovetta, A., Qichang, H., Vicentini, F., Bingkai, L., ... Yi, L. (2009). Municipal waste solid management in Pudong New Area, China. Waste Management, 29(3), 1227-1233.

Nishant.T, Prakash M.N, V. . (2010). Suitable site determination for urban waste solid disposal using GIS and Remote sensing techniques in Kottayam Municipality , India . International Journal of Geomatics and Goescieces, 1(2), 197-210.

Pasang, H., Moore, G. A., \& Sitorus, G. (2007). Neighbourhood-based waste management: A solution for waste solid problems in Jakarta, Indonesia. Waste Management, 27(12), 19241938.

Siddiqui, M., Everett, J., \& Vieux, B. (1996). Landfill Siting Using Geographic Information Systems: A Demonstration. Journal of Environmental Engineering, 122(6), 515-523.

Sujauddin, M., Huda, S. M. S., \& Hoque, A. T. M. R. (2008). Household waste solid characteristics and management in Chittagong, Bangladesh. Waste Management, 28(9), 1688-1695.

Sumathi, V. R., Natesan, U., \& Sarkar, C. (2008). GIS-based approach for optimized siting of municipal waste solid landfill. Waste Management, 28(11), 2146-2160.

Tarmidi, D. (2004). Optimalisasi Teknik Pengolahan Limbah Padat/Sampah Di Perkotaan (Studi Kasus: TPA Leuwigajah Kota Bandung). Universitas Diponegoro.

Trihadiningrum, Y. (2006). Reduction Potential of Domestic Waste solid in Surabaya City, Indonesia. In The 4th International Symposium on Sustainable Sanitation. Bandung.

Wibowo, M. (2008). Aspek Geohidrologi Dalam Penentuan Lokasi Tapak
Tempat Pembuangan Akhir Sampah ( Tpa ), 3(1), 1-6.

Windyawati, R. (2000). Prosedur Kerjasama Regional Dalam Pembangunan Dan Pengelolaan Infrastruktur. Jurnal PWK ITB, 11(3), 125-131. 